Article

\title{
Building Up a Common Recognition of City Development in the Southern Part of Kofu Basin under the Initiative of Knowledge Brokers with the Cooperation of Experts
}

\author{
Takeyasu Suzuki
}

Disaster and Environmentally Sustainable Administration Research Center, University of Yamanashi, Kofu City 400-8511, Japan; takeyasu@yamanashi.ac.jp

Received: 9 July 2020; Accepted: 2 August 2020; Published: 5 August 2020

\begin{abstract}
Extreme weather caused by global warming has caused an increase in the number and intensity of heavy rain disasters. Almost half the area of the Kofu Basin, Yamanashi Prefecture, Japan, is expected to be flooded by the largest expected rainfall in the basin. Approximately 310,000 people live in the inundation area, and the formulation of a wide-area evacuation plan in the event of a flood is an urgent issue. In the southern part of this area, where the estimated inundation depth is 5-10 m, a new station of the Linear Chuo Shinkansen Line, which will start operation in 2027, is planned, and urban development centered on the station is expected. In order to build a sustainable city that is resilient to floods in such a flood hazard area, the author established a study group on urban development consisting of knowledge brokers_-professors at University of Yamanashi-and experts with the participation of local government observers. The group has proposed a future image of sustainable Kofu Basin under the initiative of knowledge brokers with the cooperation of experts. The group attempted to put into practice the concept of sustainable cities presented by the author. As a result, by the unusual town development activities of the study group, perspective drawings that provide the participants a common recognition of the city development were successfully created.
\end{abstract}

Keywords: study group; resilient to floods; sustainable city; knowledge brokers; green infrastructure; Kofu Basin

\section{Introduction}

Extreme weather caused by global warming has resulted in an increase in the number and intensity of heavy rain disasters worldwide. For example, in Japan, since 2014, 4-6 typhoons made landfall; this number has doubled from 2.7 times, which was the average number of landings for 30 years from 1981 to 2010 [1]. The highest rainfall in the history of observations has been updated nationwide, and the use of past meteorological observation data to predict stochastic disaster events is not meaningful. In Japan, river management is determined based on the degree of importance of river management, and river facilities are designed based on the design discharge. However, there is still room for improvement in both flood control safety and its achievement compared to flood control in Europe and the United States [2].

Considering the limitation of physical measures that involve the strengthening of river facilities to protect against floods (i.e., measures to protect), a drastic change was made to more intangible measures to protect lives by evacuation by amending the Flood Control Law in 2005 (i.e., measures to evacuate) [3]. However, abnormal weather events are now at a level that cannot be matched by these measures, and floods due to the largest expected rainfall have actually occurred, and social systems have collapsed. Damage caused by the 2018 heavy rainfall disaster in western Japan and the 2019 
typhoon No.19 has indicated the need to build a city that is resilient to floods and can recover from floods quickly. Therefore, in addition to "protect" and "evacuate", it is necessary to develop a city that can escape or overcome floods and minimize damage (i.e., measures to "dodge" flood hazards). Thus, the countermeasure-dodge-which involves building a city that can maintain its function and minimize damage to the property and lives of inhabitants, is essential for sustainable cities.

For example, for the Kofu Basin, Yamanashi Prefecture, Japan, almost half the area of the basin will be flooded by the largest expected rainfall in the basin [3]. The inundation area of this basin has approximately 310,000 residents [4], and hence, the formulation of a wide-area evacuation plan against flooding is an urgent issue. In the southern part of the area, the inundation depth is estimated at 5-10 m. Here, a new station of the Linear Chuo Shinkansen Line, which will commence operation in 2027, is planned. Urban development centered on this station is expected.

The objective of the present work was to develop a basic policy for developing the Kofu Basin as a sustainable city. For this purpose, the characteristics of some well-known sustainable cities were examined. In order to embody this basic policy, the "Study Group to Promote Making the Kofu Basin Resilient against Floods" consisted of knowledge brokers-professors at University of Yamanashi-and experts and was organized with the participation of local government observers. This is an unprecedented organization that promotes city development, under the initiative of knowledge brokers with the cooperation of experts. This paper introduces the outline of the activities of the study group and presents the extracted constitutive elements considered to make the Kofu Basin a flood-resilient and sustainable city.

\section{Establishment of the Fundamental Concept of Resilient and Sustainable Cities}

\subsection{Sustainable Cities}

Population decline is a serious issue in Yamanashi Prefecture. When attractive industries concentrate in the southern part of the Kofu Basin with the opening of the Linear Shinkansen, youth can be expected to gather seeking attractive workplaces. However, the southern part of the Kofu Basin where the new station of the Linear Shinkansen will be constructed is a flood-prone zone. Furthermore, since Yamanashi Prefecture, which is rich with nature, is a tourism-oriented prefecture, the landscape of the Kofu Basin and precious flora and fauna must be preserved. In order to overcome these problems and extract the constitutive elements necessary to build a sustainable town in the southern part of the Kofu Basin, we selected three representative sustainable cities to serve as references.

Portland, US, is ranked as the most sustainable city of the 50 largest cities in the US [5]. However, the city was plagued by a serious environmental problem, namely, the pollution of the Willamette River in the past [6]. A moderate rainfall exceeded the capacity of Portland's systems, triggering combined sewer overflows of dilute, untreated sewage into the Willamette River. To cope with this problem, the city launched the $\$ 55$ million "Gray to Green" program to control stormwater runoff. The program goals included planting 33,000 yard trees and 50,000 street trees, adding 43 acres of eco-roofs, controlling invasive plant species, purchasing over 400 acres of natural areas, and constructing 920 new green street facilities in 2008 [7]. The project is considered to have resulted in the restoration of appropriate water circulation, control of flooding by decreasing and delaying stormwater runoff peak to rivers, improvement of the green and blue urban environment, and rise in the real estate value throughout the city [8]. Therefore, Portland gained worldwide attention as an advanced city with green infrastructure.

Singapore is one of the most sustainable cities in the world. The Active, Beautiful, Clean Waters (ABC Waters) Programme was launched in 2006. It transformed the water bodies in the country beyond their functions of drainage and water supply into beautiful and clean rivers and lakes with new spaces for community bonding and recreation [9]. Since its inception in 2006, the ABC Waters Programme led the way to transforming the management of surface water in Singapore-transforming the systems from functional drains to well-designed waterways that serve multiple purposes, from traditional stormwater management to sustainable stormwater management that detains and treats runoff at 
source. The ABC Waters Programme aims to seamlessly integrate the environment (green), waterbodies (blue), and the community (orange) to create new community spaces and to encourage lifestyle activities in and around the waters. As the community gets closer to water, people will better appreciate and cherish the valuable water resources and, hence, develop a sense of stewardship toward water [10].

The third city considered in this study was Stockholm, the capital of Sweden. It is famous globally for its progressive environmental and sustainable urban planning and vast urban green spaces [11]. Urban growth and the pressure for land to facilitate new development constitute the central themes in the comprehensive plan for this city since 2010: The Green Walkable City (GWC) [12].

The GWC document delves into the general trends in Swedish green space planning. In addition, it provides a broad vision of the benefits of urban greenery, promotes urban densification and ecosystem services, and presents a quality-over-quantity approach. The concerns raised by individuals and NGOs are better addressed in the document with examples and definitions in both spatial and conceptual forms. Planning, as a democratic process of inclusion, must find better methods of communicating to the public [13].

\subsection{Fundamental Concepts for a Sustainable Kofu Basin in the Future}

Green and blue environments were created to reduce river pollution and control floods in Portland, to control flooding and water supply and improve the quality of life in relation to land development in Singapore, and to promote urban densification and ecosystem services with a quality-over-quantity approach in Stockholm. The plans adopted by these three cities share a common feature, i.e., the emphasis on improving the quality of life of citizens and biodiversity. As the population tends to increase steadily in all three cities, they have been accepted as truly sustainable cities.

Let us consider the Bishan-Ang Mo Kio Park in Singapore temporarily stores stormwater from a reservoir, thereby mitigating flash flood runoff to urban areas downstream, and it usually serves as a place for citizens to relax while fulfilling a variety of functions, such as maintaining water quality, establishing clean water circulation, and maintaining biodiversity. Meanwhile, high-rise apartments are lined up on both sides of the park (Figure 1). The apartment buildings are built on pilotis with an open space on the ground floor, and they are equipped with facilities to temporarily store stormwater with the help of vegetation and gradually drain the water to Kallang River. The Bishan-Ang Mo Kio Park presents a miniature map of the development of the southern part of the Kofu Basin that was examined in this study, and it is a great reference for building the future image of Kofu Basin envisioned for 50 years to the future.

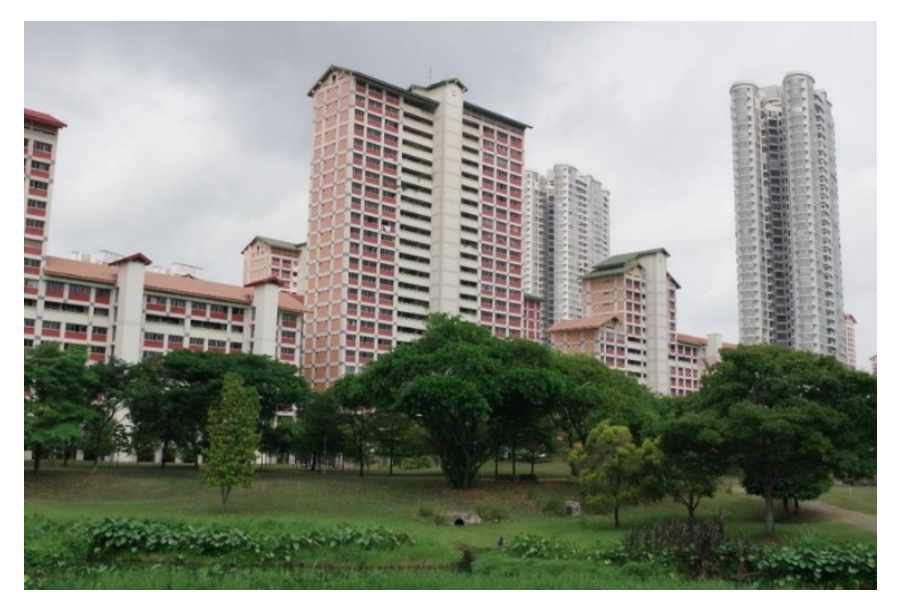

Figure 1. Picture of high-rise apartments along the Bishan-Ang Mo Kio Park (photographed by the author). 
Based on the learnings from the aforementioned sustainable cities, the following five points can be stated as the fundamental concepts for building a flood-resilient and sustainable city in the southern part of the Kofu Basin.

1. Building a green and blue garden city

2. Constructing high-rise buildings with consideration for sightseeing and landscape

3. Creating spaces and facilities for young people to gather

4. Attracting think tanks and advanced industries

5. Building roads that also serve as embankments and evacuation routes

Point 1 is also a common factor in other sustainable cities besides the above three [14,15], and it also reflects the topographical conditions of the southern part of the Kofu Basin, which is rich in water. Point 2 is necessary to effectively use the limited land that can be developed because the basin will become a blue and green city. However, sufficient consideration must be taken so that the landscape and environment of Kofu, which is rich in nature, is not damaged. Points 1 and 2 were adopted considering the urban development in Singapore. Points 3 and 4 are related to sustainable cities, where the population continues to grow, and the youth in the city need attractive workplaces as well as spaces and facilities to enjoy their leisure time. The last point, point 5, is based on the advanced flood control technology used in the Middle Ages (mid-16th century) in the Kofu Basin itself, which was a flood-prone area back then, as well.

\section{Flood Risk in the Kofu Basin}

Figure 2 shows the location of the Kofu Basin in Yamanashi Prefecture. The Eurasian Plate and the North American Plate collide from the east and west, respectively, and the highest mountain range in Japan has formed to the west of this basin. Meanwhile, the Philippine Sea Plate collides with the Eurasian Plate and the North American Plate from the south and subducts under the two plates. The Kofu Basin is located at the collision center of the three plates and has an inverted triangle shape. Additionally, it is located in the Mount Fuji volcanic belt, with Mount Fuji to its south. Aesthetically, it is surrounded by beautiful mountainous greenery and hot springs. However, the subsurface of the basin comprises a deep layer of earth from the north of the basin that collapsed because of volcanic activities. Along the perimeter of the basin, fans have formed by the supply of debris-flow deposits from mountainous rivers. During heavy rainfall, sediment and water from the surrounding mountains gather in the basin. Particularly because rivers drained flood water to the center of the basin, agriculture was not possible in this land. Since the Middle Ages, dikes were constructed, and flood control schemes were implemented to move the river channel to the edge of the basin, in an effort to turn the land into an area suitable for cultivation [16].

Figure 3 shows the main rivers and the assumed inundation on the Kofu Basin. The inundation area, which corresponds to the expected maximum rainfall (a probability of 1 every 1000 years), is depicted on the hazard map according to the categorization of the Ministry of Land, Infrastructure, Transport, and Tourism (MLIT) [17].

The Kofu Basin has a vast potential inundation area and a population that exceeds 310,000 people spread across 10 municipalities. Hence, in the event of a flood hazard, a large number of residents will have to evacuate across municipal boundaries by car. The author proposed and applied a risk communication method to the Riverside District, Chuo City (with about 1400 households and a population of about 4000), assisting in developing a community disaster management plan for wide-area evacuation without a single victim in the case of floods, and this plan has been in place for three years [13]. The next step in the method was risk communication to key stakeholders, such as national, prefectural, and municipal governments. Finally, a public symposium on large-scale evacuation in the Kofu Basin was conducted. During the panel discussion with the representatives of the Kofu River and National Road Office, prefectural government of Yamanashi, the municipality, community residents, and the author as panelists, the role of each stakeholder in wide-area evacuation 
was clarified and confirmed [4]. As a result, Yamanashi Prefecture held a meeting consisting of the prefecture and 10 municipalities in the Kofu Basin in June 2020 to prepare a wide-area evacuation plan, and they have started consideration on wide-area evacuation.

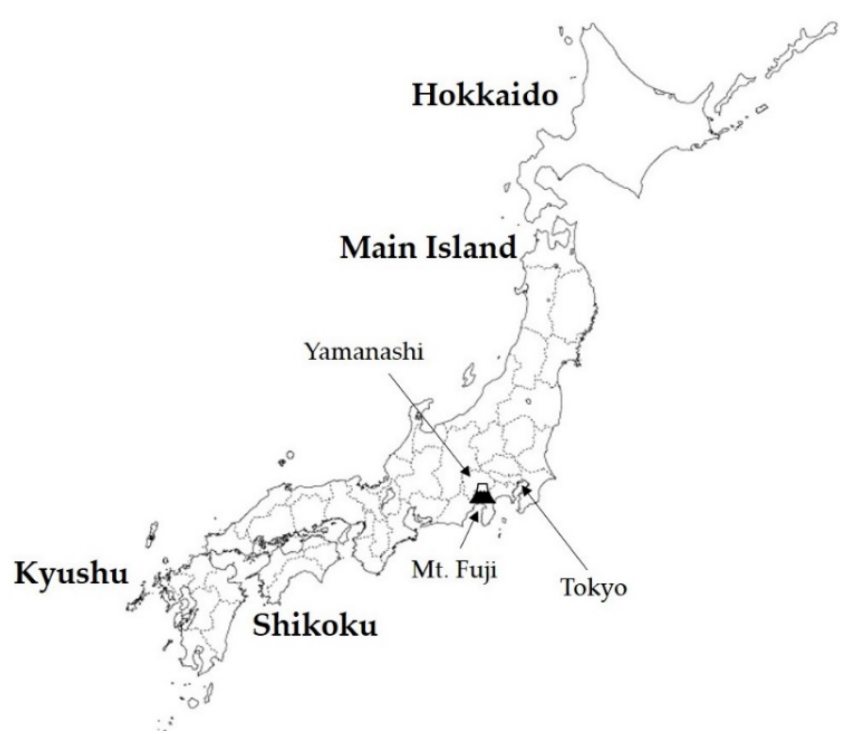

Figure 2. Japanese archipelago and Yamanashi Prefecture.

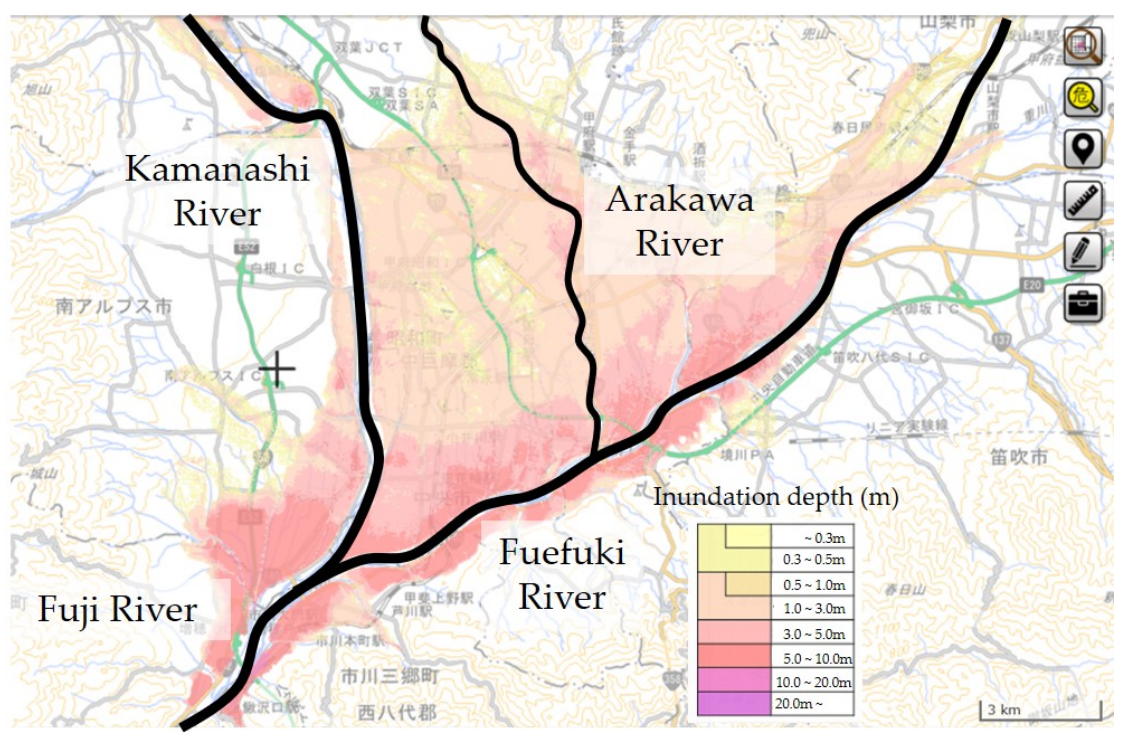

Figure 3. Main rivers and the assumed inundation area of the Kofu Basin.

\section{Study Group to Promote the Development of the Future Kofu Basin Resilient to Floods}

\subsection{Features of the Study Group}

In this research, the green infrastructure is at the core of the concept of the flood-resilient Kofu Basin 50 years into the future. Effective and smooth discussions are necessary to realize green infrastructure in local governments, and, therefore, the involvement of knowledge brokers is important. Pennel et al. [18] proposed the term "knowledge broker" for an entity who acts as the intermediary between the experts evaluating the infrastructure and the policymakers making decisions and concluded that knowledge brokers can enhance the impact of environmental research on public health by connecting the policy makers with scientific experts at critical points through the regulatory process. Chini et al. [19] remarked that the role of knowledge brokers in municipalities' green infrastructure programs offers 
opportunities for universities, research organizations, non-profits, and others to play a major role in shaping and evaluating green infrastructure systems. The study group proposes a future image of the sustainable Kofu Basin under the initiative of knowledge brokers with the cooperation of experts even though the image of the development of the Kofu Basin after the opening of the Linear Shinkansen has not been clearly stated by the local government as yet.

\subsection{Past Efforts Related to Wide-Area Evacuation}

As mentioned above, if the large-scale flood damage (Figure 3) due to a direct typhoon hit is expected in the Kofu Basin, the author proposed that a wide-area evacuation from the assumed inundation area to a safe area should be carried out at least one day before the landing of the typhoon. Suzuki et al. [20] systematically carried out risk communication with stakeholders in order to promote the study of wide-area evacuation in the region.

Suzuki [4] applied the BECAUSE model to implement risk communication to promote wide-area evacuation plan formulation and proposed a new bottom-up process with a specific evacuation plan formulation wherein the initial action is taken by community residents. In the process, the author suggested the role of each stakeholder, such as the residents of Riverside District, Chuo City, Yamanashi Prefecture, and MLIT, for the wide-area evacuation. This suggestion was accepted and mutually confirmed by involving specific sectors in a panel discussion via a disaster management symposium. Finally, the Yamanashi Prefecture secured a budget for FY2020 and decided to begin the formulation of a wide-area evacuation plan from 2020 following the author's guidance.

\subsection{Purpose of the Study Group}

A new station of the Linear Chuo Shinkansen Line (linear motor cars), which will open in 2027, is scheduled to be built in the southern part of the Kofu Basin where the assumed inundation depth ranges from 5 to $10 \mathrm{~m}$, and urban development centered on the station is expected to begin. If a new city that is resilient against floods is not built, inundation, as shown in Figure 3, will actually occur. In such an event, even if human lives were protected by wide-area evacuation, the traffic will be cut off, lifelines will malfunction, houses will be completely destroyed, and the city will be devastated. The restoration of a stricken city will be a great challenge, and both industry and residents will leave the city. Since the reconstruction of a town will incur a great deal of time and expenses, neither industry nor residents will return, and hence, reconstruction will be extremely difficult. As a result, not only the southern part of the Kofu Basin, but also Yamanashi Prefecture, which is a tourism-oriented prefecture, will suffer severe and permanent economic damages.

The study group to promote the development of a future Kofu Basin resilient to floods was established for the purpose of extracting the necessary constitutive elements for achieving the five aforementioned points for this region. The theme of the study group is "building up the Kofu Basin resilient against floods" and is not limited to the development around the Linear Chuo Shinkansen Line station. Further, it was decided that the study group will be operated by the university so that discussions can be conducted from a neutral standpoint. Thus, the University of Yamanashi, which is knowledge brokers, took the initiative in this study group and did not act as the intermediary between the experts and the policymakers as usual. Although everyone can participate, we encouraged participants from specialized fields that can contribute to join the study group. The author requested the MLIT and Yamanashi Prefecture to participate as a collaborative organization of the Disaster and Environmentally Sustainable Administration Research Center (DESiRe), University of Yamanashi, which the author presides over. The author also called on the basin municipalities, researchers, related associations, and experts (private companies and individuals) to participate in the group. In addition, the author requested the local newspaper to publish an article on the open call for participants. The activity period was scheduled from 28 August 2019 to March 2020. The results were to extract the constituent elements that make up a future Kofu Basin, which is resilient to floods, 
and organize these elements in the form of perspective drawings, and to form a common understanding of the essence of the prefectural city planning ordinance.

\subsection{Establishment of the Study Group}

Prior to the establishment of the study group in July 2019, the author had a meeting with the Deputy Governor of Yamanashi Prefecture. In the previous fiscal year, as the director of the Disaster Management Bureau of Yamanashi Prefecture, he confirmed the role that Yamanashi Prefecture should play as one of the stakeholders with regard to wide-area evacuation in the risk communication promoted by the author [4]. Since the purpose of the study group is to promote the establishment of a prefectural city development ordinance as enacted in Shiga Prefecture, Japan [21], the deputy governor could not provide an assurance of how far he could cooperate with the study group given the current situation that the project had not been recognized as a project of the prefecture.

In addition, the deputy governor replied that he would inform the directors of the Prefectural Land and Infrastructure Department and Disaster Management Bureau of this project and confirm the intention of the prefectural governor. Later, the deputy governor also reported that the Yamanashi Prefecture will have a staff member each from the two relevant departments participating in the study group as observers, in keeping with the intention of the prefectural governor.

Eventually, more than 30 participants joined the study group: four professors from the Disaster and Environmentally Sustainable Administration Research Center of University of Yamanashi, which is presided by the author; a professor emeritus of the University of Yamanashi; the Director and Deputy Director of Kofu Regional River and Road Office; a research engineer of the Public Research Institute, the MLIT; an executive from the Yamanashi Construction Industry Association; two executives from the Yamanashi Landscaping and Construction Industry Association; an architect from the Yamanashi Architects Association; two architects from the Yamanashi Architectural Design Association; a civil engineer from a general contractor; 10 construction consultant engineers from four construction consulting companies; four personnel from the Yamanashi Prefecture; and four personnel from the municipalities. The local governments or policymakers from the Yamanashi Prefecture and four municipalities were included as observers. Thus, the study group consisted of knowledge brokers-professors at the University of Yamanashi-and experts and was organized with the participation of local government observers.

\section{Activities of the Study Group}

Five study meetings were planned and held (see Table 1). At the first meeting, the author explained the purpose of the study group to the participants; thereafter, discussions were held, and a consensus was reached regarding the purpose of the study group. Next, the author requested each participant to propose specific technologies and measures required to realize the concept of city development in accordance with the established purpose by the next meeting. Figure 4 shows a photograph of the first meeting. In addition, the author explained the schedule of the study group (shown in Table 1) to each participant.

Table 1. Schedule and Content of the Study Group Meetings.

\begin{tabular}{|c|c|c|}
\hline Meet. No. & Date & Content \\
\hline 1 st & 9 August 2019 & $\begin{array}{l}\text { Explanation and consensus building } \\
\text { Request to propose technologies and measures }\end{array}$ \\
\hline 2nd & 9 October 2019 & Proposals and discussions regarding technologies and measures \\
\hline $3 \mathrm{rd}$ & 22 November 2019 & $\begin{array}{l}\text { Implementation of technologies and measures } \\
\text { Arrangement of legal issues related to proposal contents }\end{array}$ \\
\hline 4th & 8 January 2020 & $\begin{array}{l}\text { Summary of basic concept } \\
\text { Preparation for making perspective drawings (presenting storyboards, discussion) }\end{array}$ \\
\hline 5 th & 4 March 2020 & $\begin{array}{c}\text { Bringing up perspective drawings, presentation and deliberation of the final report draft (outline) } \\
\text { Request to create a report (individual content explanation) } \\
\text { Confirmation of division of roles in disaster management symposium }\end{array}$ \\
\hline
\end{tabular}




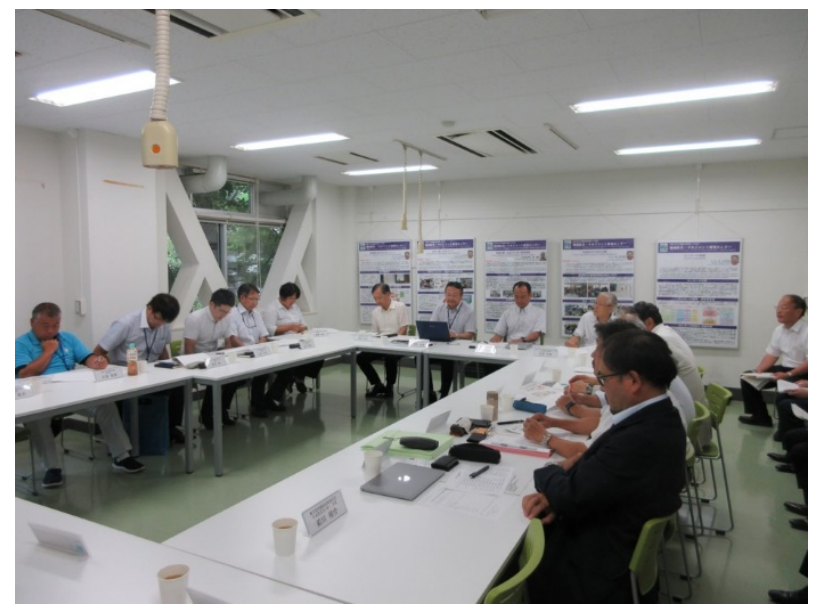

Figure 4. Photograph of the first meeting.

At the 2nd meeting, the technologies and measures proposed by the participants were discussed. The proposal materials are roughly classified into five items, namely, high-rise buildings and facilities, embankments and roads, inland flooding, disaster information system, and legal systems. Representative proposals were introduced and discussed for each item.

High-rise buildings and facilities include public facilities, high-rise integrated residential facilities, facilities built on artificial ground, raised residential land, inflated flooded areas, raised evacuation sites, embankments, and viaducts. Embankments and roads include traditional flood control dikes, high-standard roads, and highway embankments. Inland flooding is concerned with drainage from bypass tunnels, tributary rivers and sediment dredging, flood storage below the facility, and reservoirs. The disaster information system includes observation, warning, evacuation guidance, lowland invasion and safety measures, information transmission and sharing, rescue, evacuation routes, and evacuation sites. The legal system deals with the induction and promotion of relocation from hazard areas by restraining development and land use, with the obligation to disclose hazard information in land transactions, and inducing relocation by taxation.

The author asked each group to conduct a study to further substantiate the above five items. At the 3rd meeting, the author asked each group to report the results. Regarding the legal system, the Prefectural Land and Infrastructure Department of the Yamanashi Prefecture compiled and reported regarding the relevant legal system. The author presented a storyboard for the landscape of the Kofu Basin 50 years into the future; the storyboard incorporated the embodied technology and measures. In this drawing, the entire southern part of the Kofu Basin was transformed into a nature museum. The nature museum has the function of a detention/retention basin, which is a reservoir for the temporary storage of flood waters from rivers. In this storyboard, the industrial, education, research, and residential zones formed by raising the land were drawn, and the transportation network connecting these raised lands, the new station of the Linear Chuo Shinkansen Line, and the center of Kofu City were configured.

The idea of the nature museum is based on the utilization of green infrastructure for inland flood control, namely Eco-DRR, which seeks to reduce disaster risks by harnessing the disaster prevention and mitigation functions of healthy ecosystems [22,23]. The green and blue infrastructure policy has excellent performance as demonstrated in Singapore and Portland, and this proposal also adds the use of valuable animals and plants from the viewpoint of conservation; moreover, the functions of research, education facilities, and leisure facilities are also achieved by utilizing the rivers, waterfronts, and green areas. This storyboard cultivated a common recognition among the study group participants regarding the development of a city that is resilient to flood.

The author invited an expert in perspective drawing (perspective drawing creator) to participate in the 3rd meeting and provided the expert with the materials for the meeting and explanations of 
the unclear points. Based on the results of the 3rd meeting, the expert provided a sketch (storyboard) before making the perspective drawings. However, the author made many requests to the expert, checked the results, and requested corrections before the storyboard was completed as intended. At the 4th meeting, four storyboards were presented, and the participants discussed them. Finally, a common image of the future Kofu Basin, which is resilient to floods, was formed by modifying the storyboard. In addition, the author instructed the perspective drawing creator to correct the storyboard according to the suggestions provided in the 4th meeting and then create the perspective drawings, and provided the outline of the study results compiled by the author.

After the 4th meeting, the author scrutinized each perspective drawing in detail, ordered multiple revisions, and finally obtained five perspective drawings. In addition, the author summarized the results of the study group. At the 5th meeting, the author showed these results to the participants and requested that the participants suggest the points to be corrected and reviewed. The corrections regarding the perspective drawings were immediately sent to the perspective drawing creator, and the author confirmed that the creator understood the corrections properly. In addition, the author also requested the participants create explanatory materials on individual technologies that should be published after the summary of the results. Furthermore, it was determined that the results of this study group would be presented at the disaster management symposium on 18 March 2020, and at the symposium, each person in charge of the explanatory materials for individual technologies would make a presentation.

\section{Perspective Drawings of the Kofu Basin 50 Years into the Future and the Major Individual Technologies Required}

\subsection{Basic Policy for Perspective Drawings}

While showing perspective drawings, the author will explain the Kofu Basin 50 years into the future. The future basin is envisioned as highly resistant to flood damage and resilient to floods. The author will present the image and the constitutive elements that make up the future Kofu Basin. Therefore, the author will not necessarily portray the future of any particular district in the Kofu Basin.

It is necessary to induce a proper relocation of residences from the dangerous flooded areas to the safe areas in order to realize the city in the perspective drawings. In addition, it is essential to establish a legal system for designating the southern part of Kofu as detention/retention basins and developing the Kofu Basin as a sustainable city. Therefore, perspective drawings were created for the purpose of promoting activities for establishing an ordinance to make the Kofu Basin resilient to floods.

\subsection{Water Detention/Retention Basin}

A wide area of the Kofu Basin gets flooded by river water, not only during the assumed maximum flood that occurs once every 1000 years, but also during the planned flood that is the design basis of the levees. In particular, in the southern part of the Kofu Basin, the right bank of the Fuefuki River dams the inundation flow, increasing the inundation depth and further expanding the vast flooding area where people are unable to save their lives by vertical evacuation to the second floor of their homes (Figure 3). The study group proposed that the entire area where the assumed inundation depth exceeds $3 \mathrm{~m}$ in the planned flood or $5 \mathrm{~m}$ in the assumed maximum flood should function as a detention/retention basin. In addition, in order to prevent large-scale damage due to bank breakage, the traditional flood control method of the kasumi-tei should be revived for large rivers such as Kamanashi and Fuefuki Rivers, and the water that overflows through the kasumi-tei should be stored in a detention/retention basin. It is important to lead the water to a detention/retention basin.

Figure 5 shows a perspective drawing showing the southern part of the Kofu Basin 50 years into the future. It was prepared by the perspective drawing creator, based on the sketch created by the author on the development image of the southern part of the Kofu Basin, and was supervised by the author. Rapid rivers originating in the mountains surrounding the Kofu Basin frequently get flooded. 
The flood waters flow into the large Kamanashi and Fuefuki Rivers, causing frequent floods in the Kofu Basin. Thus, the Kofu Basin, and especially its central and southern regions, was unsuitable for tillage until the Middle Ages. This basin was a flood-prone area, and rice was not cultivated here. Shingen Takeda, who was a powerful feudal lord who ruled this area in the Middle Ages, ordered a large-scale change of river channels and the construction of dikes under the magistrate of construction service at that time. Through continued flood control thereafter, rice cultivation commenced in the Kofu Basin. At that time, various flood control methods were devised and tested; one of these methods was the kasumi-tei.

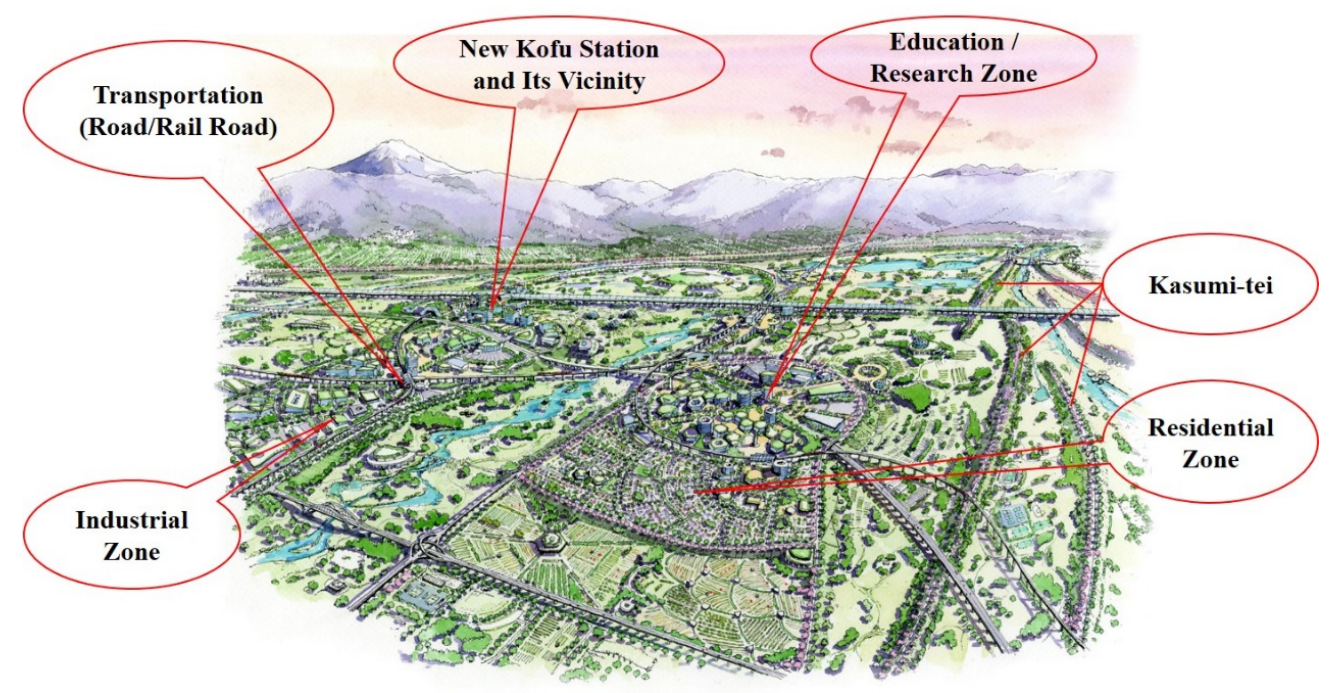

Figure 5. Perspective drawing for the southern part of the Kofu Basin 50 years into the future.

Figure 6 shows a representative diagram of the kasumi-tei. It is a discontinuous embankment or an open levee system shaped as trails of walking geese. When the water level rises during a flood, it acts as a reservoir for water between adjacent levees and stores the water that flows out from the main stream. If the water level increases further, the water overflows from the upstream end of the embankment, but the amount and momentum of the water are extremely small compared to the case where a part of the continuous embankment breaks. In addition, if the water level of the river drops owing to the subsidence of the flood, the water accumulated in the basin between the levees will naturally flow down and return to the main streams. By employing the kasumi-tei and flood control forest, the flood control technology to dampen floods and guide water to a water detention/retention basin is revived in the perspective drawing. Figure 7 shows a recent photograph of the embankment on the left bank of the Kamanashi River where the kasumi-tei was first constructed in the Middle Ages.

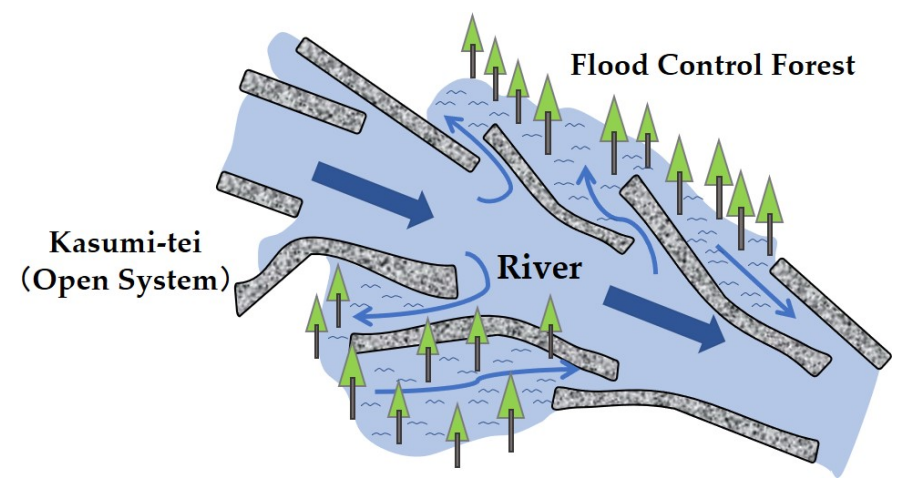

Figure 6. Representative diagram of the kasumi-tei. 


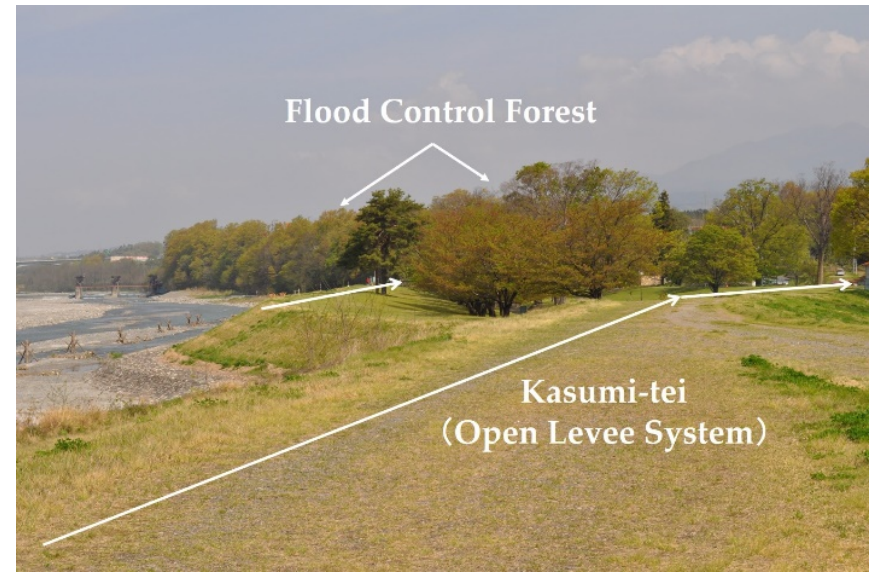

Figure 7. Photograph of the left bank of the Kamanashi River with traces of the former kasumi-tei.

\subsection{Retention/Detention Basin within the Natural Museum}

A water detention/retention basin is not a useless wetland. When people reach the new Kofu Station on the Linear Chuo Shinkansen Line, they will see another world of green and blue (Figure 8). The whole area will be a unique nature museum. The basin will act as a conservation site for valuable flora and fauna via the restoration and protection of the waterfront. Figures 8-11 were drawn by the perspective drawing creator, and reflected the opinions of the participants of the study group, and were finally edited by the author. Figure 9 shows the perspective drawing of the southernmost landscape of the nature museum. A freshwater aquarium and botanical garden will be set up. The nature museum will be a place for ecological exhibits. It is envisioned as an interactive educational and leisure space where people can play with water and aquatic life and indulge in fishing, boating, canoeing, bird watching, nature observation, insect collection, and so on. In addition, the basin will be a center for environmental and biological ecology experiments (on water quality, freshwater ecology, and terrestrial flora and fauna), and researchers and children can visit the museum for training.

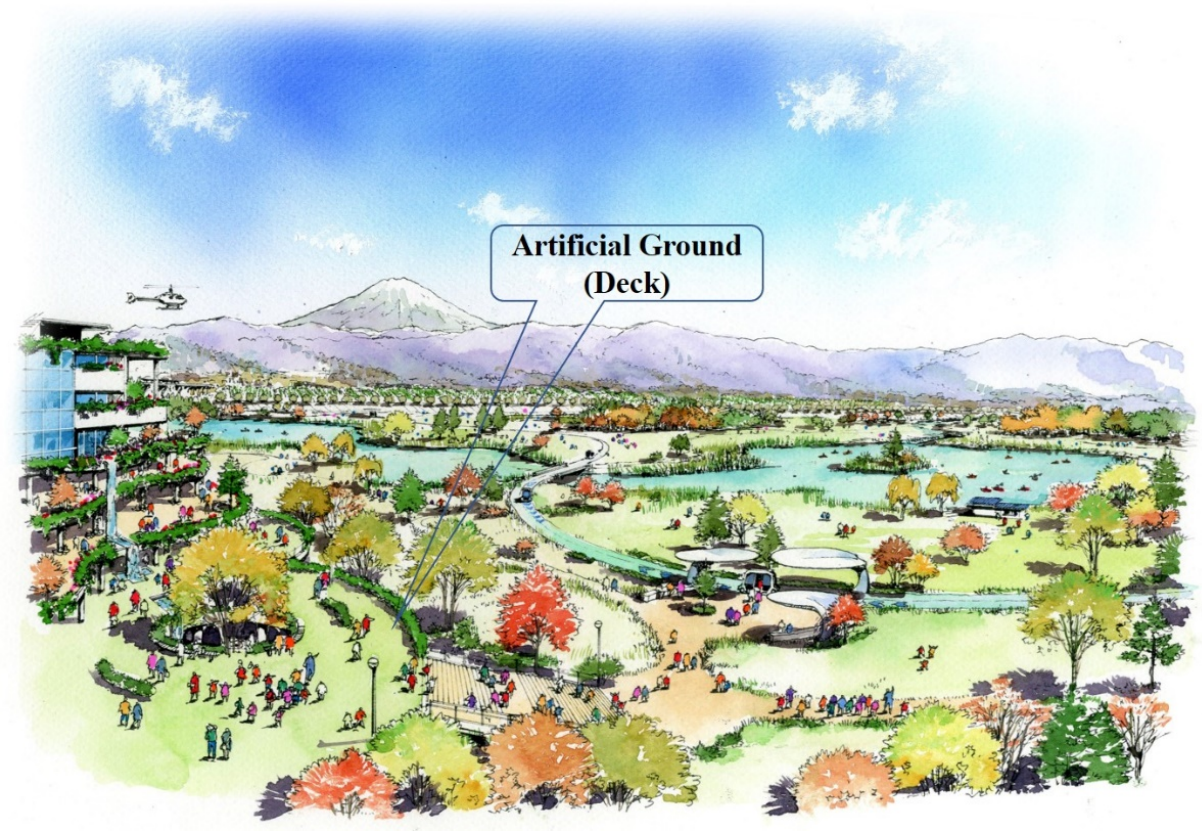

Figure 8. Perspective drawing of the water detention/retention basin near the New Kofu Station on the Linear Chuo Shinkansen Line. 


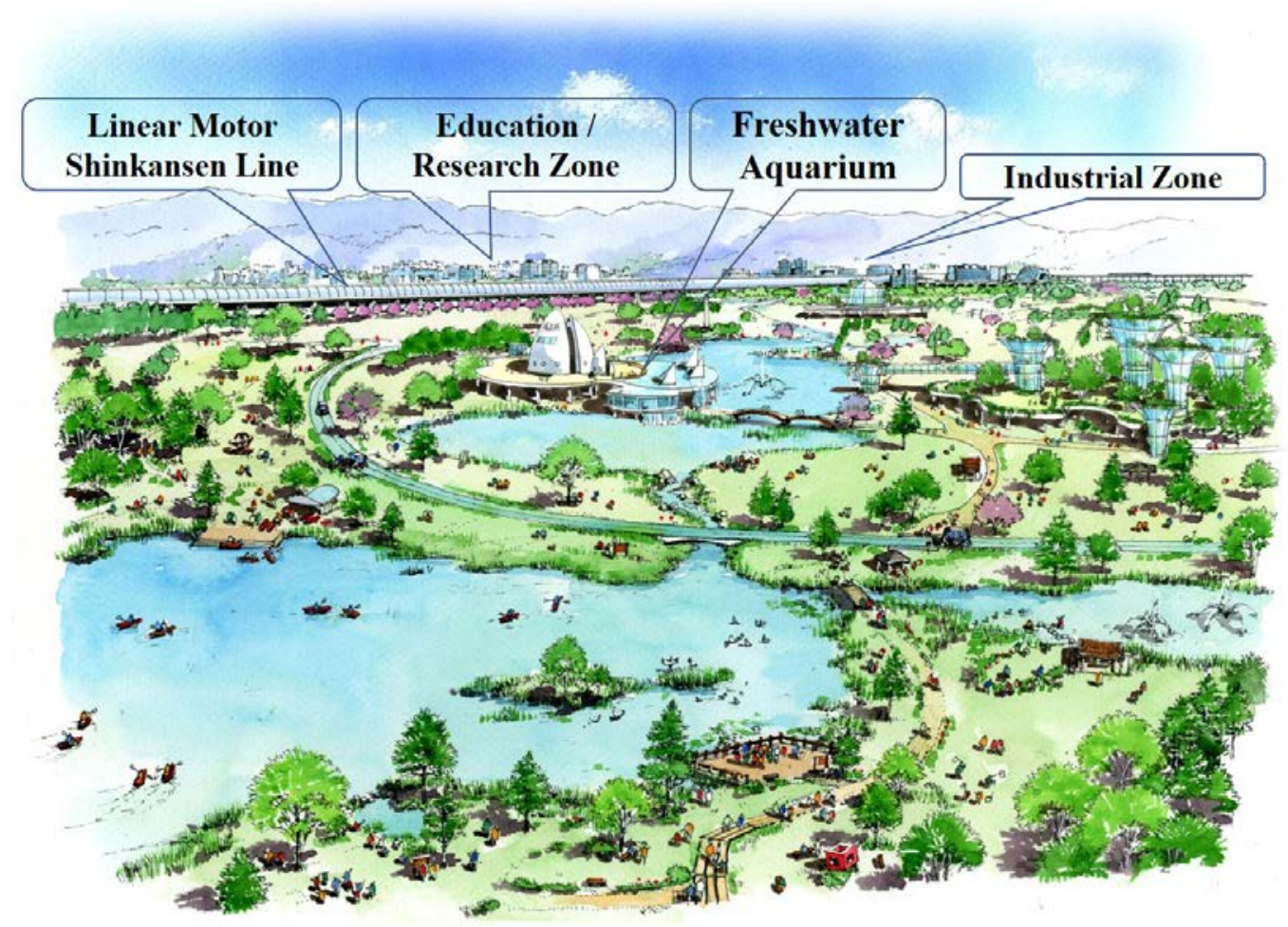

Figure 9. Perspective drawing of the southernmost part of the nature museum.

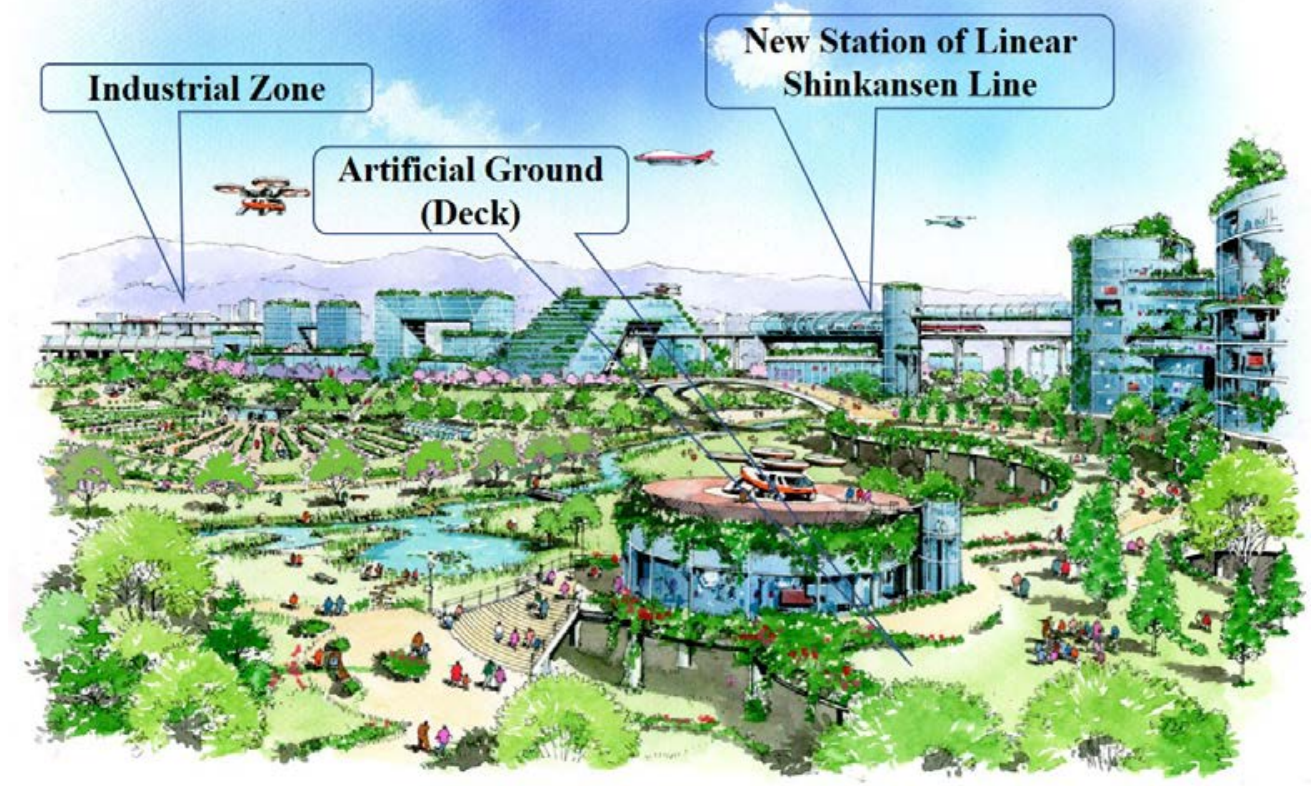

Figure 10. Perspective of the north exit of New Kofu Station in a normal situation. 


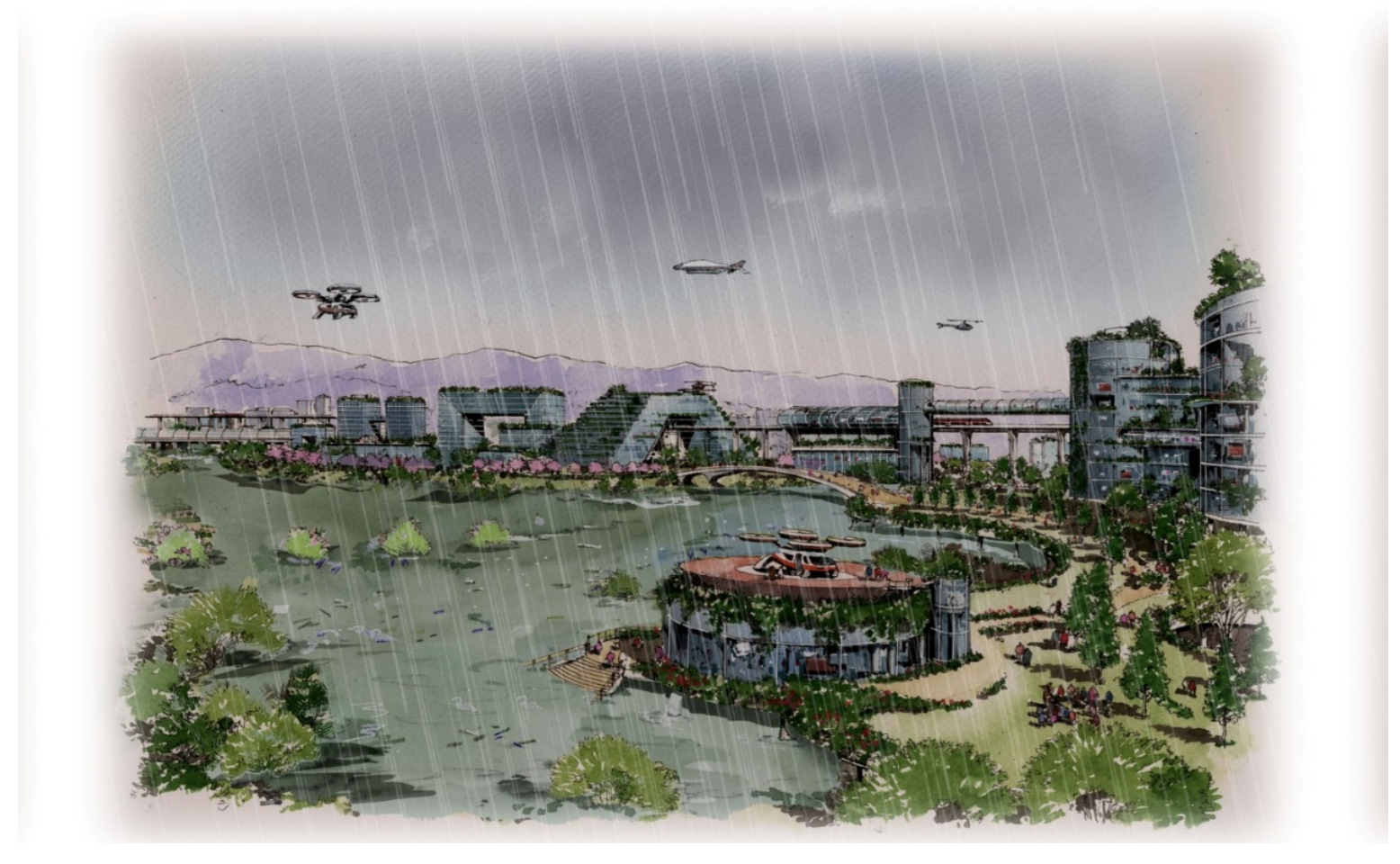

Figure 11. Perspective of the north exit of New Kofu Station in the event of a flood.

\subsection{Stay-Type Leisure Facilities}

The nature museum will be equipped with hands-on educational and leisure facilities such as those for water sports, fishing, boating, bird watching, nature observation, insect collection, and agricultural experiences. Facilities for environmental, biological, and ecological research and education, disaster management research and education, and international conference halls will be built here. Figure 10 shows a perspective view drawn in a composition looking north from the New Kofu Station on the Linear Chuo Shinkansen Line. There will also be a sports camp and a stadium for professional soccer teams in the district. Each facility will welcome visitors with the highest level of hospitality. Accommodation will be provided for tourists, researchers, and trainees, both domestic and international. In order to ensure the safety of the facilities, an advanced disaster information system will manage the entrance and exit from the museum and guide the people in the event of a disaster. Not only in the nature museum, but also in the education and research zone and industrial zone, large-scale facilities useful for disaster management employing advanced technology will be provided.

\subsection{Raised Safety Area (Education and Research Zone, Advanced Industrial Zone, and Residential Zone)}

To the north of the nature museum, a raised and safe land that will not be flooded will be constructed, and an education and research zone, an advanced industrial zone, and a residential zone will be built there. Universities and research institutes will be established located in the education and research zone. Ecological exhibitions (freshwater aquarium, botanical garden) will be conducted in a dedicated space nearby, and this zone will be the center of environmental, biological, and ecological research and education and disaster management research and education. We also propose that the southern part of the Kofu Basin should be developed as a center of cutting-edge research and education in order to create a safe and secure super city that makes full use of information and communications technology (ICT) and artificial intelligence (AI).

We propose that the industrial zone should be located adjacent to the New Kofu Station, on the north side, considering the convenience of transportation. Since abundant groundwater is supplied to 
this area, a food factory using this groundwater can be established here. Further, we hope that the collaboration with cutting-edge research in the education and research zone will attract industries in the fields of biotechnology, environmental technology, etc., and industries with cutting-edge technologies such as AI, ICT, and medical care, thereby creating employment opportunities for the youth.

The residential zone will be set up as a living space for the youth employed in the industrial zone and education and research zone. Necessary public facilities will be provided here for the common welfare and convenience of residents. This zone will be a relocation destination or a new alternative for the present residents of the dangerous inundation area.

\subsection{Transportation Network}

JR Kofu Station-Advanced Industry Zone-Linear Station-Nature Museum-Research and Education Zone-Residential Zone, etc. will be connected by rail (light rail, etc.) or road. The recommended structural type of railways and roads is embankment or viaduct based, in order to prevent flooding. In 50 years from the present, perhaps many new personal and public aerial vehicles may be available, but we do not consider the possibility here.

\subsection{Artificial Ground and High-Rise Buildings Essential for the Southern Part of the Kofu Basin}

In the assumed inundation area with an estimated inundation depth of $3 \mathrm{~m}$ or more, we propose to construct a facility on an artificial ground (deck). In particular, it is suggested that areas where the inundation depth exceeds $5 \mathrm{~m}$ basically function as a detention/retention basin, and middle- to high-rise buildings should be built on an artificial ground constructed $10 \mathrm{~m}$ above the ground surface there. Some functions of hospitals and offices of the Yamanashi prefectural government and Kofu City will be located here to fulfill the functions of the local disaster countermeasure headquarters. Lifeline facilities such as water, electricity, gas, and telecommunications will also be installed on the artificial ground, and most social systems will function normally even if a flood occurs.

Figure 10 shows a perspective drawing of the north exit of New Kofu Station in a normal situation. The artificial ground and high-rise buildings will be used as emergency evacuation sites during the flood for residents who not yet been relocated. In addition, each building should be equipped with facilities that can work as a temporary shelter for victims. The artificial grounds will be connected to each other by bridges, and thus, an evacuation route to the shelter will be available. All buildings will have rooftops, walls, balconies, and gardens with the function of temporarily storing rainwater with the aid of vegetation and delaying the runoff of stormwater. We will devise energy-saving measures such as cooling the building using the abundant water.

Figure 10 depicts the normal situation, while Figure 11 shows the perspective of the north exit of New Kofu Station during a flood, drawn in the same composition as Figure 10. The green space temporarily stores the flood waters. In addition, the safety of the residence spaces of people is ensured, and the functions of lifelines, too, are maintained.

\section{Publication of the Result Report}

The Yamanashi Prefecture is the only entity that will enact the ordinance to promote building a future Kofu Basin resilient to floods, and municipalities will carry out city development according to the ordinance. Therefore, the activity results of our study group will be utilized by the Yamanashi Prefecture to realize flood-resistant, sustainable city development. Therefore, the author assigns the utmost importance to risk communication with the Yamanashi Prefecture. Three staff members of the Yamanashi Prefecture who were included in the study group reported the activities of the study group to the governor and deputy governor and other executives. However, the author thought it important to also directly report the results to the governor, deputy governor, and the executives of related departments of the prefectural government of Yamanashi and to encourage them to respond.

When the result of the study group will be announced in the disaster management symposium held by the study group, the media will ask the governor about the response of the prefectural 
government to our suggestion. Therefore, the author visited the Yamanashi prefectural government office on 10 February 2020, before the 5th meeting was held. The author explained the results before being authorized at the 5th meeting to the deputy governor and directors of disaster management department and the prefectural land and infrastructure department using an interim report of the study group. This interim report was provided to the governor by these executives. The director of the Disaster Management Department informed the author that the governor had officially decided to dispatch officials from the Yamanashi Prefecture to the study group and to actively cooperate with the group to make the Kofu Basin more sustainable.

Although the disaster management symposium was held despite the situation created by the spreading of the coronavirus infection, there was a demand for social distancing at meetings involving a large gathering of people. Hence, the presentation was in a form similar to a press release. That is, in the presence of the press, the author reported a summary of the results, and the other participants made announcements regarding the individual technologies in their charge. The achievement report was released as a pdf file [24]. The symposium was recorded as a video and posted on YouTube [25,26]. At the disaster management symposium, we initially planned to hold a panel discussion that would enable us to exchange opinions with stakeholders, but in the wake of the coronavirus pandemic, we decided to cancel this discussion.

\section{Concluding Remarks}

The southern part of the Kofu Basin, Yamanashi Prefecture, Japan, is a region with a high risk of flood damage. This region has no safe upland, and the depth of inundation is expected to be high. A new station for the Linear Motor Chuo Shinkansen Line is planned to be constructed here, and the station is expected to be a center for urban development for the neighborhood. In order to build a sustainable city that is resilient to floods in such a flood hazard area, the author established a study group on urban development. This group has proposed a future image of the sustainable Kofu Basin under the initiative of knowledge brokers and with the cooperation of experts. The group applied the concept of sustainable cities presented by the author and proposed the building of detention/retention basins; a nature museum; stay-type leisure facilities; raised ground created by banking, artificial land and high-rise buildings; and a transportation network - these formed the constituent elements of the sustainable Kofu Basin that is resilient to floods. Thus, by the unusual town development activities of the study group, perspective drawings that provide the participants a common recognition of the city development were successfully created.

By incorporating these constituent elements, image perspective drawings of the entire southern part of Kofu Basin as well as some specific parts were made corresponding to the development envisioned 50 years into the future. The report of the study group was prepared by putting together these perspective drawings and their explanations. This achievement was reported to the governor and the executives of the Yamanashi Prefecture. A supplementary explanation of each component was added to this report, and the final results report of the study group was compiled. These achievements were made accessible to the citizens of the prefecture via social media, the homepage of our research center or the author's homepage, and mass media. The prefectural governor decided to actively involve the staff in the future management of the study group. The concrete examination for realizing a flood-resilient Kofu Basin will now enter the stage of drafting the prefectural ordinance on flood control and urban development, along with a further realization of the components. The study group intends to continue its activities for another year while maintaining neutrality and increasing the contribution of the Yamanashi Prefecture and municipalities. Thus, we are just getting started with sustainable urban development of the southern part of the Kofu Basin. In the fundamental steps of an effective process in making a move towards a more sustainable urban development that Yigitcanlar et al. [27,28] proposed, we are only in the second step out of 14 steps in total. 
Funding: This research was funded by University of Yamanashi the 2019 Regional Promotion Project Research Grant.

Acknowledgments: The author would like to thank Suetsugi, Hada, and Yaegashi of University of Yamanashi who participated in this study group as knowledge brokers, sincerely addressed each issue, and made suggestions based on their specialized knowledge. In addition, the author would like to thank Emeritus Hanaoka for participating in the study group as an expert in urban planning and for giving me advice. These professors are scholars who specialize in city planning, river engineering, diversity of aquatic organisms, phase-free disaster prevention facilities, and so on. They suggested important matters to be considered for city development based on their respective specialized fields, and supplemented the knowledge and experience lacking for the author who specializes in disaster management planning and regional disaster management. The author would like to express my deep gratitude to those who participated in the study group as experts. Yasutani, Kaneko, Deputy Director of Kofu Regional River and Road Office, the MLIT provided the necessary materials from the perspective of the river administrator. Otsuki, a research engineer of the Public Works Research Institute made various concrete suggestions based on his knowledge of green infrastructure. Ten construction consultant engineers from four construction consulting companies helped create perspective drawings of the Kofu Basin 50 years into the future using their expertise and experience. In particular, Sora of Oriental Consultants, Iida of Pacific Consultants Co. Ltd., Maekawa of Construction Technology Research Institute Co., Ltd., and Yokouchi of Sanpoh Co., Ltd. took the lead in summarizing each constitutive element of technology. Hirata of Kurosawa Construction Co., Ltd. presented the prestressed concrete structure of the artificial ground. The associations participating in this study group, such as the Yamanashi Construction Industry Association, the Yamanashi Landscaping and Construction Industry Association, the Yamanashi Architects Association and the Yamanashi Architectural Design Association, evaluated perspective drawings and actively proposed solutions to problems. Furthermore, the author would like to express my sincere gratitude to Takai and Watanabe of Sampo Co., Ltd. for their efforts as the secretariat of this study group.

Conflicts of Interest: The author declares no conflict of interest.

\section{References}

1. Japan Meteorological Agency. Typhoon Normal Value. Available online: https://www.data.jma.go.jp/fcd/ yoho/typhoon/statistics/average/average (accessed on 10 July 2020).

2. Japan Institute of Construction Engineering (JICE). Flood control project implementation system in European countries-Flood control project plan based on climate change. JICE Rep. 2011, No.111001. (In Japanese)

3. Suzuki, T. 9.3 Legal Systems. In Disaster Engineering; Riko Tosho: Tokyo, Japan, 2019; pp. $287-299$. (In Japanese)

4. Suzuki, T.; Watanabe, T.; Okuyama, S. Facilitating risk communication for wide-area evacuation during large-scale floods. Int. J. Environ. Res. Public Health 2019, 16, 2466. [CrossRef] [PubMed]

5. Mega, V. Quintessential Cities, Accountable to the Future: Sustainability, Innovation and Citizenship; Springer Science and Business Media: Berlin, Germany, 2013.

6. Stoddard, A.; Harcum, J.B.; Simpson, J.T.; Pagenkopf, J.R.; Bastian, R.K. 13. Willamatte river case study. In Municipal Wastewater Treatment: Evaluating Improvement in Natural Water Quality; John Willey \& Sons: London, UK, 2002.

7. City of Portland Bureau of Environmental Service. Portland's Green Infrastructure: Quantifying the Health, Energy, and Community Livability Benefits; ENRIX Inc.: Portland, OR, USA, 2010.

8. Liu, J.H. Portland Green Loop Economic Analysis, Northwest Economic Research Center Publications and Reports, Portland State University. 2016. Available online: https://pdxscholar.library.pdx.edu/cgi/ viewcontent.cgi?article=1025\&context=nerc_pub (accessed on 10 July 2020).

9. Yau, W.K.; Radhakrishnan, M.; Liong, S.Y.; Zevenbergen, C.; Pathirana, A. Effectiveness of ABC waters design features for runoff quantity control in urban Singapore. Water 2017, 9, 577. [CrossRef]

10. Public Utilities Board, Singapore. Singapore, Active, Beautiful, Clean Waters Design Guidelines, 4th ed.; Public Utilities Board: Singapore, 2019.

11. Röschel, L.; Davis, M.; Naumann, S. Integration user preferences into urban green and blue infrastructure planning: Insight from Halle, Germany and Stockholm, Sweden. WIT Trans. Ecol. Environ. 2019, 238, $233-244$. [CrossRef]

12. The Walkable City Stockholm City Plan. Available online: http://international.stockholm.se/globalassets/ ovriga-bilder-och-filer/the-walkable-city---stockholm-city-plan.pdf (accessed on 14 June 2020).

13. Littke, H. Planning the green walkable city: Conceptualizing values and conflicts for urban green space strategies in Stockholm. Sustainability 2015, 7, 11306-11320. [CrossRef] 
14. Ruá, M.J.; Huedo, P.; Cordani, L.; Cabeza, M.; Saez, B.; Agost-Felip, R.A.Q.U.E.L. Strategies of urban regeneration in vulnerable areas: A case study in Castellón, Spain. Sustain. City XIII 2019, 238, 481-492. [CrossRef]

15. Meihnen, F.; Martinez, A.; Marti, N. Re-naturalization of the city of Barcelona, Spain: Introducing greenery in Mederranean buildings. Sustain. City XIII 2019, 238, 301-309. [CrossRef]

16. Suzuki, T. risk communication in order to facilitate community resilience against a large-scale flood. WIT Trans. Built Environ. Disaster Manag. Hum. Health Risk VI 2019, 190, 145-155.

17. Ministry of Land, Infrastructure, Transport and Tourism, Japan, Hazard Maps that Can Be Overlaid. Available online: https://disaportal.gsi.go.jp/maps/ (accessed on 10 July 2020).

18. Pennell, K.P.; Thompson, M.; Rice, J.W.; Senier, L.; Brown, P.; Suuberg, E. Bridging research and environmental regulatory processes: The role of knowledge brokers. Environ. Sci. Technol. 2013, 47, 11985-11992. [CrossRef] [PubMed]

19. Chini, C.M.; Canning, J.F.; Schreiber, K.L.; Peschel, J.M.; Stillwell, A.S. The green experiment: Cities, green stormwater infrastructure, and sustainability. Sustainability 2017, 9. [CrossRef]

20. Suzuki, T.; Hada, Y.; Miyamoto, T. Application of the BECAUSE model to establishment of a collaboration system with relevant administrative agencies for regional evacuation due to large river flooding capability and training process of its introduction. J. Disaster Inf. Stud. 2016, 14, 105-115. (In Japanese)

21. Ohara, M.; Sawano, S.; Banba, M.; Nakamura, H. Analysis on people's attitude to strategies for promoting local activity to change ways of living in the area at flood risk. J. Jpn. Soc. Nat. Disaster Sci. 2017, 36, 91-107. (In Japanese)

22. Nature Conservation Bureau, Ministry of Environment, Papan. Ecosystem-Based Disaster Risk Reduction in Japan. A Handbook for Practitioners. 2016. Available online: http://www.env.go.jp/nature/biodic/ecodrr/ pamph04.pdf (accessed on 10 July 2020).

23. Renaud, F.G.; Nrhren, U.; Sudmeier-Rieux, K.; Estrella, M. Development and opportunities for ecosystem-based disaster risk reduction and climate change adaptation. In Ecosystem-Based Disaster Risk Reduction and Adaptation in Practice (Advances in Natural and Technological Hazards Research); Springer: Cham, Switzerland, 2016; pp. 1-20.

24. Disaster and Environmentally Sustainable Administration Research Center, University of Yamanashi. The Achievement Report of the Study Group to Promote the Kofu Basin Resilient against Floods. Available online: http://www.ccn.yamanashi.ac.jp/ \{\}takeyasu/pdf/kofu_project(20200323).pdf (accessed on 10 July 2020).

25. The Study Group to Promote the Kofu Basin Resilient Against Floods, Disaster Management Symposium on the Kofu Basin 50 Years into the Future (1). Available online: https://www.youtube.com/watch?v= BEPxcrmvNiU\&feature=youtu.be (accessed on 10 July 2020).

26. The Study Group to Promote the Kofu Basin Resilient Against Floods, Disaster Management Symposium on the Kofu Basin 50 Years into the Future (2). Available online: https://www.youtube.com/watch?v= ptX657CZeho\&feature=youtu.be (accessed on 10 July 2020).

27. Yigitcanlar, T.; Kamruzzaman, M. Planning, development and management of sustainable cities: A commentary from the guest editors. Sustainability 2015, 7, 14677-14688. [CrossRef]

28. Yigitcanlar, T.; Kamruzzaman, M.; Teriman, S. Neighborhood sustainability assessment: Evaluating residential development sustainability in a developing country context. Sustainability 2015, 7, 2570-2602. [CrossRef]

(C) 2020 by the author. Licensee MDPI, Basel, Switzerland. This article is an open access article distributed under the terms and conditions of the Creative Commons Attribution (CC BY) license (http://creativecommons.org/licenses/by/4.0/). 